Janusz Ziembiński (Katowice)

\title{
Manu propria. Wpis Olbrychta Karmanowskiego do Liber amicorum Andrzeja Lubienieckiego
}

Niespodziewaną, zdawałoby się, cechą „wieku rękopisów” jest bardzo słaba obecność autografów wśród rękopiśmiennych przekazów utworów poetyckich z epoki. Wiersze czołowych twórców okresu baroku znamy przeważnie (jeśli nie wyłącznie) z nieautoryzowanych odpisów. Znaczący jest przykład Daniela Naborowskiego: dysponujemy jedynie autografami listów poetyckich, potraktowanych jako korespondencja i przechowanych właśnie w zbiorach listów. W kilku imionnikach zachowały się też jego wpisy pochodzące z czasów studenckich peregrynacji ${ }^{1}$.

Możemy więc mówić o szczęściu, gdyż w zasobach Archiwum Radziwiłłów dotrwał do naszych czasów niewielki zespół listów Karmanowskiego ${ }^{2}$, poety wydobytego z rękopiśmiennych sylw epoki. Listów wierszowanych, jak się wydaje, Karmanowski nie tworzył, wpisał się jednak na kartach należącego do Andrzeja Lubienieckiego Pamiętnika przyjaciót zachowanego w zbiorach Biblioteki Czartoryskich ${ }^{3}$. To

1 Por. A. Golik-Prus, Wpisy Daniela Naborowskiego do alba amicorum, „Pamiętnik Literacki” LXXXVIII, 1997, z. 4, s. 145-151.

2 Por. [Listy Olbrychta Karmanowskiego], AGAD, Archiwum Radziwiłłów, dz. V, t. 140, nr 6437. Edycja krytyczna: O. Karmanowski, Wiersze i listy, wyd. R. Grześkowiak, IBL, Warszawa 2010, s. 65-87.

3 Por. Liber amicorum Andreae Lubieniecii, rkps Biblioteki Czartoryskich w Krakowie, sygn. 1403. Obszerne omówienia zawartości: A. Brückner, Dwa świadectwa. Szkic obyczajowy i literacki, „Biblioteka Warszawska” 1904, t. 3, s. 497-543; A. Jarosz, "Liber amicorum” Andrzeja Lubienieckiego w kręgu myśli i poezji ariańskiej, w: Studia bibliologiczne, t. 8, red. A. Jarosz, UŚ, Katowice 1994, s. 37-56. 
jedyny tekst o charakterze literackim, którym dysponujemy, a także jedyny fragment polskiego wiersza zapisany ręką własną poety. Dlatego też okruch ten zasługuje na uwagę, choć jego autorski status - jak zwykle w podobnych wpisach sztambuchowych - nie jest do końca jasny.

Wpis jest niedatowany, co w Liber amicorum zdarza się dość często, można jednak ustalić, kiedy go dokonano: między 8 października 1617 r. (data na poprzedniej stronie - s. 55) a 29 tegoż miesiąca (s. 65), a więc - prawdopodobnie - w pierwszej połowie października ${ }^{4}$. Wyraźnym, starannym pismem nakreślił Karmanowski tekst sentencji:

Vita n[ost]ra nihil aliud est quam comoedia, cuius ultimus actus de morte agitur. Tota Philosophia, ut inquit Plato, nihil aliud est, quam commentatio mortis. Cur enim praecepta bene vivendi discimus, nisi ut bene mori sciamus.

Pod spodem następowała dedykacja, wydobyta większym wcięciem:

Virtute, pietate atque omni genere eruditionis praestantissimo viro, Generoso D[omi]no Andreae Lubieniecki a Lubieniec [wyrazy nieczytelne] $\mathrm{D}$ [omi] no ac tutori plurimum colendo, hoc amoris perpetui et observantiae signum posuit

Albertus Karmanowski manu $\mathrm{p}[\mathrm{rop}] \mathrm{ria}$

Dedykacje łacińskie przeważały w Liber amicorum, ale nie były reguła, podobnie jak użycie łaciny w samym tekście dedykowanym: oba elementy mogły być sformułowane w różnych językach. Choć sporo w imionniku Lubienieckiego wpisów różnokształtnych, nawet ekscentrycznych

4 Pod datą 8 X 1617 r. na s. 55 mamy wpis Piotra Morzkowskiego; 28 X na s. 64 wpisał się Lambertus de Maiche Aurelianus (błąd zapisu miesiąca: november; wpis następny - pod datą 29 X na s. 65 znajduje się wpis Piotra Lubienieckiego). Zwrócił na to uwagę K. Borzęcki, który jako pierwszy opublikował też cały wpis Karmanowskiego (Id., O Olbrychcie Karmanowskim, poecie-arianinie (Zebranie znanych i kilka nowych szczegótów o życiu i twórczości), RwP 1928, s. 99). Por. też wydanie całego wpisu wraz z polskim przekładem w Opisie źródet edycji R. Grześkowiaka (O. Karmanowski, op. cit., s. 98-99).

5 Późniejsze w stosunku do wpisów zamazania żółtą farbą (por. A. Brückner, op. cit., s. 501). 
$\mathrm{w}$ formie $\mathrm{e}^{6}$, najbardziej rozpowszechniony jest schemat najprostszy: najpierw właściwy wpis (czasem cytat określony przywołaniem źródła, biblijnego lub antycznego), później hołdownicze jego przypisanie.

Karmanowski dostosował się do tej formuły, ale i wyszedł poza nią: podpisawszy się pod dedykacją, nakreślił jeszcze pod spodem dwa łacińskie aforyzmy oraz ich przekłady w postaci pary ośmiozgłoskowych wierszy polskich:

\author{
Amicitia quae desinere potest, vera nu[m]qua[m] fuit \\ Przyiazn ktora się rozrywa \\ Nigdy nie była prawdziwa. \\ Benevolentiae vinculum no[n] est rumpen[dum] sed solve[ndum] \\ Związek chęci nie targány \\ Ale ma bydz rozwiązány.
}

Można przypuścić, że wpisując się do imionnika, nie planował zrazu ich umieszczenia, w przeciwnym wypadku zapisałby je przed dedykacją. Z drugiej strony nie bardzo pasowały one do egzystencjalnej powagi i ciemniej tonacji głównego wpisu. Być może zostały dodane, aby myślami o prawdziwej przyjaźni uzupełnić konwencjonalną dedykację o bardziej osobisty akcent ${ }^{7}$. Schemat klamry - zamknięcia aforyzmem wpisu rozpoczętego aforyzmem - spotykany jest zresztą w filotece Lubienieckiego ${ }^{8}$. Nawet urywkowa i „ogólnoludzka” wzmianka o przyjaźni wydać się może „ciepła” na tle poważnego timbru myśli dedykowanych szacownemu starcowi, którym był w wieku 67 lat Lubieniecki, uważany za moralny autorytet, „wzór świątobliwości”

6 Oznacza to pewien nadmiar przytoczeń, nawet w kilku językach, niekiedy wyraźnie zmierzający w stronę erudycyjnego popisu (cytaty w językach orientalnych). Por. Liber amicorum, s. 61-64, 77, 88, 94-100, 126-127, 190, 209.

7 Tylko z dużą ostrożnością można szukać osobistych odniesień w tej silnie skonwencjonalizowanej materii, jednak czytelnikowi znającemu zarys biografii Karmanowskiego narzuca się obserwacja, że brak tu wzmianki o bliższych związkach pomiędzy wpisującym a właścicielem imionnika: Andrzej Lubieniecki był w końcu bratem Stanisława, ojczyma poety (bliskość braci potwierdzają ich wpisy w imionniku).

$8 \mathrm{Na}$ stronach poprzednich, przed wpisem Karmanowskiego (s. 1-55): s. 14, s. 36, s. 44 (rymowana włoska sentencja). Co ciekawe - bezpośrednio poprzedzający wpis (s. 55) ma również tę postać: po dedykacji umieszczono jeszcze łaciński cytat ze św. Augustyna. 
i otoczony - to stały motyw przypisań - powszechnym szacunkiem? Samo też miejsce, gdzie wpisów dokonywano i do którego odwiedzający przybywali często z dalekich stron niby do „Nowego Jeruzalem” kościoła „chrystiańskiego”, skłaniało do poważnej i religijnej refleksji. Ten rodzaj przypisań dominuje, wśród przytoczeń przeważają cytaty biblijne. Często pojawiają się także wpisy przekazujące refleksję ogólnohumanistyczną, jak zresztą we wszelkich ówczesnych imionnikach. Pamiętnik przyjaciót Lubienieckiego buduje literacką w istocie rzeczywistość trafnie opisaną przez Edmunda Kotarskiego: „Jesteśmy w świecie skonwencjonalizowanych wypowiedzi, grecko-rzymskich i biblijnych toposów. Powielane, niezwykle często przywoływane, nie traciły wszakże na znaczeniu; były monetą obiegową, pobudzającą zawsze jednak bogate skojarzenia myślowe. Pozostawały w kręgu takich motywów jak fortuna i virtus, nobilitas, patientia, peregrinatio, prudentia, niosły z sobą treści patriotyczne, wkraczały w dziedzinę relacji między człowiekiem a Bogiem. Miały najczęściej postać maksymy, sentencji moralnej o charakterze homogenicznym, których znajomość respublica litteraria czerpała nierzadko z popularnych już w XVI wieku florilegiów, takich na przykład, jak Flores Hesperidum (1574) czy Album failiare Stammbuch sive disticha moralia latinograeca et germanica in studiosorum iuvenum usum mire apposita (1587)" 10 .

Klasycy starożytni cytowani są w Liber amicorum wielokrotnie najbardziej popularnym źródłem przytoczeń był Seneka (cytuje go np. szwagier Karmanowskiego, Mikołaj Cettis; s. 221) ${ }^{11}$.

Wpis autora Pieśni pokutnych cytatem nie jest; powołuje się wprawdzie na Platona, ale raczej referując myśl filozofa. Trudno orzec, czy trzyzdaniowy aforyzm wystylizował sam wpisujący, czy też przejął go z jakiejś skarbnicy podobnych sentencji. Raczej to drugie - wpis ma charakter opracowanej literacko całości: dwie platońskie myśli połączone są powtórzeniem („nihil aliud est...”). Przynajmniej jedną z nich można nazwać

9 Por. J. Tazbir, Wstęp, w: A. Lubieniecki, Poloneutychia, oprac. A. Linda, M. Maciejewska, J. Tazbir, Z. Zawadzki, PWN, Warszawa-Łódź 1982, s. VIII.

10 E. Kotarski, O imionnikach XVI i XVII wieku, w: Staropolska kultura rękopisu, red. H. Dziechcińska, IBL, Warszawa 1990, s. 102.

11 Także: s. 14, 161, 162, 208, 212, 221. Inni cytowani klasycy to: Cyceron (s. 162, 260-261), Sokrates (s. 199, 237), Plutarch (s. 41), Sofokles (s. 172), Menander (s. 172), Juwenalis (191), Persjusz (s. 258), Wergiliusz (s. 260-261), Izokrates (s. 237). 
toposem - w dziejach literatury i kultury niezwykle płodnym: „Vita nostra nihil aliud est quam comoedia, cuius ultimus actus de morte agitur" ${ }^{\prime 2}$.

Nieco bardziej ograniczony kulturowo zasięg miała przywołana w drugim zdaniu definicja filozofii jako przygotowania do śmierci, pochodząca z Fedona. Motyw ten pojawił się również u Cycerona, Seneki, w neoplatońskich komentarzach do Arystotelesa z V w., w pismach ojców kościoła - Kasjodora i Jana Damasceńskiego ${ }^{13}$. Według tej definicji uprawianie filozofii mieści się w kategoriach praktycyzmu i rozumiane jest jako etyczne postępowanie opierające się na obiektywnym ontologicznie systemie wartości duchowych. Podobnie filozofię platońską jako oparty na fundamencie nauki o ideach zespół wartości etycznych, a w konsekwencji również określony sposób życia i formowania samego siebie - pojmował także Erazm ${ }^{14}$.

Taka interpretacja określenia Platona uwzględnia kontekst dzieła filozofa, sama formuła prowokuje jednak do odczytania uproszczonego, które było zapewne popularne, miało też swoją tradycję, a ta - swój udział w przemianach kultury: „O ile wczesny humanizm był apoteozą życia obywatelskiego, apoteozą budowania przez człowieka w pełni jego wolności ziemskiego państwa, u schyłku wieku XV następuje zdecydowany zwrot w kierunku kontemplacji i odsunięcia się od świata. Miejsce pogodnej afirmacji życia [...] zajmuje platonizm ze swą ascetyczną atmosferą i filozofia rozumiana jako przygotowanie do śmierci"15.

To uproszczone rozumienie definicji z Fedona utrwaliło się zapewne dzięki współbrzmieniu z obecnym w kulturze chrześcijańskiej - a zrodzonym być może we wczesnochrześcijańskim monastycyzmie i ascetyzmie - patrzeniem na życie człowieka w kontekście jego kresu. Umieszczenie

12 O źródłach toposu i jego literackim wykorzystaniu por. J. Kotarska, Topos theatrum mundi' w poezji przetomu XVI i XVII wieku, w: Przetom wieków XVI i XVII w literaturze i kulturze polskiej, red. B. Otwinowska, J. Pelc, Ossolineum, Wrocław 1984, s. 145-169; Id., "Jesteśmy jakby na gre persony ubrane... ". Barokowe wersje toposu 'theatrum mundi', w: Id., Theatrum mundi. Ze studiów nad poezją staropolska, Wydawnictwo UG, Gdańsk 1998, s. 5-42.

13 Por. A. Nowicka-Jeżowa, Pieśni czasu śmierci. Studium z historii duchowości XVI i XVII wieku, Towarzystwo Naukowe KUL, Lublin 1992, s. 6, przyp. 3.

14 Por. J. Domański, Erazm i filozofia. Studium o koncepcji filozofii Erazma z Rotterdamu, Ossolineum, Wrocław 1973, s. 179.

15 E. Garin, Filozofia odrodzenia we Wtoszech, przeł. K. Żaboklicki, PWN, Warszawa 1969, s. 111. 
śmierci w centrum życia, bliskie nurtowi contemptus mundi, było też stałym motywem chrześcijańskiej parenezy, niezależnie od wyznania.

Oba zdania wpisu mówią w gruncie rzeczy o tym samym. Obecny w pierwszym topos theatrum vitae humanae od starożytności nacechowany był moralistycznie, co dobitnie określił Johan Huizinga: „Lecz jeśli przyjrzymy się bliżej temu porównaniu życia do sztuki teatralnej, okaże się, iż wykoncypowane na platonicznych zasadach nosi w sobie niemal wyłącznie tendencję moralną. Było ono po prostu odmianą starego tematu vanitas, smutnym westchnieniem nad marnością wszystkiego, co ziemskie, i niczym więcej" ${ }^{\prime 6}$.

W formie podanej przez Karmanowskiego istotą teatru życia nie jest wymienność życiowych ról człowieka, ale ostatni akt - śmiertelny finał: mors ultima linea rerum. Oba zdania spięte są powtórzonym, jednoznacznym wskazaniem (,jest niczym innym, jak...”). Trzecie - wobec tej jednoznaczności - to już nawet nie pytanie o pożytek „uczenia się dobrego umierania”. Cały aforyzm jest - użyjmy i my tego zwrotu niczym innym jak memento mori.

Ta „myśl nienowa” wyposażona jednak została w bogate humanistyczne i klasyczne odwołania. Nawet skojarzenie z rozkwitłym u schyłku średniowiecza, ale popularnym i później piśmiennictwem nurtu ars bene moriendi nie jest konieczne: wątek uczenia się dobrego życia i dobrej śmierci odnaleźć można w dziełach rzymskich klasyków ${ }^{17}$.

Tekst wpisu zaczerpnięty prawdopodobnie z jakiegoś zbioru aforystycznych przytoczeń i opracowann ${ }^{18}$, a może częściowo samodzielnie wystylizowany, posiada szczególną autonomię znaczeniową - nie możemy określić powodów jego wyboru przez wpisującego. Przynajmniej w tym wypadku: poważny, mówiący o sprawach egzystencjalnych (choć pozbawiony bezpośrednio religijnej wymowy) - jest po prostu odpowiednio dobrany do okoliczności i osoby właściciela imionnika. Bardziej osobisty stosunek wpisującego wyrażać może zamykający całość łaciński dwuwiersz o nierozerwalności przyjaźni. Identyfikacja autorstwa w Nowym Korbucie („Aforyzmy wpisu są parafrazą odnośnych wierszy

16 J. Huizinga, Homo ludens. Zabawa jako źródto kultury, przeł. M. Kurecka, W. Wirpsza, Czytelnik, Warszawa 1985, s. 17.

17 Por. M. Włodarski, „Ars moriendi” w literaturze polskiej XV i XVI w., Universitas, Kraków 1987, s. 17-19 (o piśmiennictwie XVII w. na s. 254-258).

18 Zob. O. Karmanowski, Wiersze i listy, s. 98, przyp. 2: przykłady źródeł, w których dwa pierwsze zdania wpisu występują w brzmieniu bardzo zbliżonym. 
z Owidiusza „Amores” ${ }^{19}$ jest błędna, a opiera się na niewłaściwym odczytaniu wzmianki Kazimierza Borzęckiego ${ }^{20}$. Źródłem pierwszej formuły jest list św. Hieronima do mnicha Rufina ${ }^{21}$. Trudniej wskazać autora drugiej - uzupełniającej - choć podobną myśl znajdujemy w $D e$ amicitia Cycerona, najbardziej zapewne znanym dziele poświęconym przyjaźni ${ }^{22}$. Całość pochodzić może również z jakiegoś kompendium zestawionego dla celów praktycznych.

O polskim przekładzie tej sentencji (dwa zdania stanowią niewątpliwie jedność) trudno właściwie mówić jako o utworze poetyckim, choć dokumentuje on sprawność tłumacza: dosłowność, ekonomię słowa i gładkość zdania. W rozprawie omawiającej Liber amicorum A. Brückner zauważył: „Olbrycht pisze naturalnie wiersze polskie”23. Nie jest to jednak tak oczywiste i prowokuje, by zapytać: dlaczego właściwie końcowa para łacińskich sentencji została przełożona przez Karmanowskiego polskim wierszem, skoro cały jego wpis (łącznie ze zlatynizowaną formą własnego imienia) utrzymany był konsekwentnie w języku łacińskim? Być może to swoista autoprezentacja na terenie cudzych myśli i przytoczeń, gdzie nawet wpisanie własnego utworu byłoby jeszcze jednym cytatem. Przekład łacińskiego aforyzmu na polski wiersz - pokaz umiejętności technicznych - jest niczym dodatkowe przedstawienie się wpisującego, identyfikujące go jako członka zbiorowości ludzi pióra, jak złożony na końcu podpis: „jestem poetą”. O znaczeniu twórczości literackiej dla samego autora mówią też dwa naśladowane ze starożytnych dłuższe wiersze (O śnie, Do Zazdrości), zachowane w Wirydarzu poetyckim Jakuba Teodora Trembeckiego, najbogatszej poetyckiej sylwie „wieku rękopisów”.

19 Por. Bibliografia Literatury Polskiej „Nowy Korbut”, t. 2: Piśmiennictwo staropolskie, red. R. Pollak, PIW, Warszawa 1964, s. 312.

20 „Tłómaczenia [!] i imitacje: De requisitis formosae feminae carmina z Melandera, Potegga biatychgtów - z Anakreonta, aforyzmy z pamiętnika Lubienieckiego i Do zazdrości - naśladownictwo (jak zdołałem ustalić) z Amores Owidjusza [...]”, K. Borzęcki, op. cit., s. 101.

21 Por. „Miłości nie można z niczym porównywać. Umiłowanie nie ma ceny. Przyjaźń, która może się urwać, nigdy prawdziwa nie była”, Św. Hieronim, Listy, przeł. i przedm. J. Czuj, t. 1, PAX, Warszawa 1952, s. 14.

22 Por. „Sam słyszałem, jak Katon powiedział, że należy je raczej z wolna rozsupływać niż nagle przecinać [...]”, M. T. Cyceron, Leliusz o przyjaźni, przeł., oprac. i wstęp J. Korpanty, WL, Kraków 1992, s. 56. Te same źródła obu sentencji podaje także R. Grześkowiak (O. Karmanowski, op. cit., s. 162).

23 A. Brückner, op. cit., s. 514. 
Nie sposób rozumieć ich inaczej niż jako wypowiedzi o sobie samym, nawet intymne wyznania. Znaczeniowym jądrem obu utworów jest stwierdzenie własnej przynależności do rodziny poetów, uczestnictwa w tradycji łączącej starożytnych i współczesnych. W małej liczbie znanych utworów Karmanowskiego to obecność znacząca, zwłaszcza że refleksja nad dziełem własnym i cudzym pojawia się i w innych drobniejszych lirykach tak w tonacji żartobliwej, jak i całkiem serio ${ }^{24}$.

Zapis w Liber amicorum - choć jeden $\mathrm{z}$ wielu podobnych w sztambuchu - w pewien sposób koresponduje więc z twórczością autora i jej znaczeniem dla niego samego. Przede wszystkim jednak stał się ewenementem w tym życiorysie ubogim w fakty, niejako wyrwane z kontekstu przez kapryśny los, decydujący o zachowaniu bądź zniszczeniu dokumentów. Dzięki owemu zapisowi w biografii Karmanowskiego, dotąd kojarzonego jednoznacznie z litewskim kręgiem birżańskich Radziwiłłów, niespodziewanie pojawił się nowy, ariański wątek. Nie dziwi więc, że dysponujący tak skąpymi źródłami autorzy dotychczasowych prób biografii autora Pieśni pokutnych wyraźnie przeceniali związek poety z rakowskim środowiskiem zborowym ${ }^{25}$.

Nie ma przede wszystkim żadnych dowodów na studia Karmanowskiego w Akademii Rakowskiej, co więcej, zdecydowanie przemawia przeciw temu chronologia. Jeśli poeta urodził się najwcześniej (i najprawdopodobniej) w roku 1580 - świadczy o tym dokument odnaleziony przez

24 Por. Na swoje fraszki, Drwa, Piotrowi Kochanowskiemu, autorowi przetożenia „Gofreda”; wszystkie wiersze pochodzą z rkpsu BN BOZ 1162, tytuły wg wydania R. Grześkowiaka.

25 Mowa przede wszystkim o zarysie biograficznym K. Gajdki, Ptatnik z pusta skrzynia. Nowe szczegóty na temat Olbrychta Karmanowskiego, OiRwP 2005, 49. Autor zebrał rozproszone ustalenia poprzedników, a także wyniki własnych badań i stworzył plastyczną biograficzną całość. Niestety, przy pozorach ścisłości wielokrotnie wyciąga nieuprawnione wnioski, snuje fantastyczne spekulacje, często podkolorowując suche fakty, jednym słowem - daje się ponieść temperamentowi opowiadacza, zamiast skrupulatnie ważyć drobne wzmianki i ślady, z jakich zmuszeni jesteśmy budować zarys biografii autora Pieśni pokutnych. Szersza wersja artykułu Gajdki w jego pracy poświęconej środowisku birżańskiemu, jeszcze bardziej rozrzutnie szafuje dowolnymi skojarzeniami i domniemaniami - K. Gajdka, Literatura, propaganda, stużba. Ludzie pióra w otoczeniu Radziwittów birżańskich w pierwszej potowie XVII wieku, Wydawnictwo Naukowe Semper, Warszawa 2009, s. 92-133. R. Grześkowiak, wydawca Wierszy i listów Karmanowskiego w otwierającym tom zwięzłym Wprowadzeniu do lektury oparł się w zasadzie na ustaleniach Gajdki, jednak odrzucił bądź sprostował jego najbardziej niefortunne pomysły i pominął zbyt daleko idące spekulacje. 
Wacława Urbana - to w chwili powstania Akademii Rakowskiej miałby 22 lata. Nawet gdyby urodził się nieco później (powiedzmy w roku 1585), co znacznie mniej prawdopodobne, musiałby wstąpić do Gimnazjum Rakowskiego dopiero w wieku 18 lat. Trudno przypuścić, aby ojczym przyszłego poety, Stanisław Lubieniecki starszy, któremu sprawy edukacji leżały na sercu, nie dopilnował rozpoczęcia przez pasierba edukacji we właściwym momencie ${ }^{26}$, tym bardziej że istniała wówczas szkoła ciesząca się uznaniem zboru. Hipoteza o nauce w gimnazjum Wojciecha z Kalisza w Lewartowie była już wysuwana (K. Borzęcki, J. Dürr-Durski) i pasuje doskonale do znanej nam dziś (choćby w przybliżeniu) daty urodzin Karmanowskiego. Uczniem szkoły lewartowskiej mógł być w latach 1594-1598, w najlepszym okresie gimnazjum, zakończonym zresztą jego nagłą likwidacją w roku 1598. W tym czasie ministrem w Lewartowie był Krzysztof Lubieniecki (starszy), brat Stanisława i Andrzeja.

$\mathrm{Na}$ Raków wskazywano natomiast, powołując się (z braku innych przesłanek) na monograficzny artykuł Stanisława Tynca omawiający powstanie i dzieje tamtejszego gimnazjum. Materiały pozwalające zidentyfikować studentów są bardzo skromne, a nazwisko Karmanowskiego w artykule nie pojawia się wcale. Kluczowa wzmianka znalazła się dopiero w podsumowującym rozszerzeniu, które Tync dodał w przedruku studium w zbiorowym tomie Raków - ognisko arianizmu. W tym eseistycznym fragmencie „Karmanowscy” to jedna z wielu ariańskich rodzin, „których synowie popłynęli falą do szkoły rakowskiej”27. Można przypuścić, że właśnie obecność wpisu Olbrychta w sztambuchu Lubienieckiego podpowiedziała Tyncowi, nieznającemu powiązań rodzinnych pisarza, jego nazwisko.

26 Zaświadcza to jego imiennik, autor Historia reformationis Polonicae, według którego uczelnia rakowska powstała dzięki staraniu Stanisława starszego. Por. S. Lubieniecki, Historia Reformationis Polonicae, tum Reformatorum, tum Antitrinitariorum origo et progressus in Polonia et finitimis provinciis narrantur, Johannes Asconius, Freistadii (Amsterdam) 1685, s. 239. Stanisław Lubieniecki starszy był scholarchą (opiekunem) uczelni rakowskiej, nie zaś jej wykładowcą, nie można więc powiedzieć, że hipotezę studiów poety w Rakowie „uprawdopodabnia fakt, że w Akademii Rakowskiej nauczał ojczym Olbrychta, Stanisław Lubieniecki”, R. Grześkowiak, Wprowadzenie do lektury, w: O. Karmanowski, op. cit., s. 9, przyp. 15.

27 Por. S. Tync, Wyższa szkota braci polskich w Rakowie. Zarys jej dziejów (1602-1638), w: Studia nad arianizmem, PWN, Warszawa 1959; przedruk w: Raków-ognisko arianizmu, red. S. Cynarski, PWN, Kraków 1968 (dodany fragment na s. 165). 
Brak też dowodów na stały pobyt Karmanowskiego w Rakowie. Nazwisko poety w „Inwentarzu” długów sporządzonym po śmierci Aleksego Rodeckiego (1606) to nie dowód „obracania kapitałem”28, a tym bardziej przebywania z dłużnikiem w jednym miejscu - rakowski drukarz mógł zaciągnąć pożyczkę, korzystając choćby z pośrednictwa Stanisława Lubienieckiego. Jeśli Karmanowski „posiadał w Rakowie nieruchomość” ${ }^{29}$, to przez kilka minut: tyle, ile trwało podpisanie dokumentu jej przejęcia, a następnie - innego - sprzedaży. Księgi miejskie, dziś dostępne jedynie w odpisach Stanisława Kota, zawierają bowiem notkę o takiej transakcji, będącej najwyraźniej sposobem na otrzymanie gotówki od szwagra, Mikołaja Cettisa (po śmierci ojca, Jana Baptysty, głowy rodziny Cettisów), tytułem uregulowania należności spadkowych czy może wypłaty sum posagowych $(1616)^{30}$. Rodzinę Cettisów, a więc swą przyszłą żonę Wiktorię poznać musiał Karmanowski w Rakowie, gdzie Cettisowie posiadali dom $^{31} . Z$ podobnych zapisów spraw spadkowych, dotyczących tym razem Otwinowskich, rodziny matki poety, zdaje się jednoznacznie wynikać, że Urszula Lubieniecka z Otwinowskich, primo voto Karmanowska, nie żyła już w 1613 r. ${ }^{32}$ Mogła jednak umrzeć nawet wiele lat przed tą datą, a jej

28 K. Gajdka, Ptatnik z pustą skrzynia, s. 172.

29 Ibidem.

30 „Nicolaus Cettis spadek po ojcu Janie, w Rakowie dom na Nowym Rynku daje Olbrychtowi Karmanowskiemu. Olbrycht Karmanowski z Wiktorią Cettisówną, małżonką, dom ten sprzedaje Andrzejowi Chrząstowskiemu za 200 złp i zobowiązuje się za Julię Cettisównę małżonkę Jana Bębnowskiego, Elżbietę - Tobiasza Morsztyna i Konstancję - Stanisława Mirzyńskiego", Z. Pietrzyk, Wypisy Stanistawa Kota do dziejów Rakowa, OiRwP 1987, 32, s. 191, nr 89.

31 R. Grześkowiak (por. Id., Wprowadzenie do lektury, s. 10, przyp. 19) słusznie uznał, że „uśmiercenie” (w pracach K. Gajdki) Wiktorii Cettisówny przed 1627 r. w świetle dzisiejszych źródeł uznać należy za przedwczesne. Do argumentów badacza można dodać znacznie szerszy w czasach staropolskich zakres znaczeniowy określenia „siostra”, o czym zresztą sam Gajdka wspomina w innym miejscu, por. Id., Literatura, propaganda, stużba, s. 87. Np. A. Lubieniecki młodszy nazwa tak w listach Jadwigę z Greków Kuroszową, wdowę po Stanisławie (matkę swej synowej). Także sama fakcja magnacka była wspólnotą „panów szwagrów” i w jej ramach określenie „szwagier” wzmacniało nawet odległe powinowactwo, U. Augustyniak, Dwór i klientela Krzysztofa Radziwitta (1585-1640). Mechanizmy patronatu, Wydawnictwo Naukowe Semper, Warszawa 2001, s. 123, przyp. 106.

32 „Debora Dąbska z mężem Andrzejem ceduje prawa dziedziczne po ojcu Erasmusie na dom przy ulicy Starej Szydłowskiej siostrze Judycie Małgorzacie i Piotrowi Zagórskim oraz szwagrowi swemu Stanisławowi Lubienieckiemu (19 IV 1613)”, Z. Pietrzyk, op. 
stałe zamieszkiwanie w Rakowie przyjmujemy jedynie jako prawdopodobne $-\mathrm{w}$ istocie nie zachowały się o tym żadne wzmianki ${ }^{33}$. Nie ma też żadnych śladów pełnienia przez Karmanowskiego jakichkolwiek funkcji zborowych, jak w przypadku ojczyma, co - dla człowieka jego stanu - byłoby warunkiem koniecznym osiedlenia w Rakowie. Związek Karmanowskiego z miastem nad Czarną, choć niewątpliwy, nie był więc tak oczywisty i ścisły, jak to zwykle przyjmowano: bywał on tam jedynie gościem.

O udziale poety w rokoszu Zebrzydowskiego nie wiemy prawie nic tyle tylko, że był obecny w obozie pod Jeziorną: jego podpis figuruje na akcie wypowiedzenia posłuszeństwa królowi, 24 czerwca 1607 r. ${ }^{34}$ Uczynił to więc niejako wbrew tradycji rodzinnej Lubienieckich, zdecydowanych regalistów ${ }^{35}$. Nie powinno to dziwić, gdyż związki przyszłego autora Pieśni pokutnych z rakowskim kręgiem rodzinnym i zborowym określić należy poza, być może, okresem dzieciństwa - jako raczej luźne. Nie należał Karmanowski do grona intelektualistów zborowych, służących

cit., s. 189, nr 73. W pozostałych zapisach o transakcjach majątkowych Stanisław Lubieniecki nie występuje razem z żoną. Nieobecność Urszuli Lubienieckiej Gajdka tłumaczy faktem, że „mąż był naturalnym opiekunem żony w sprawach spadkowych czy posagowych”, Id., Literatura, propaganda, stużba, s. 87, tyle że w przytaczanych zapisach żony występują zawsze z mężami. W żadnych zachowanych adnotacjach o transakcjach majątkowych nie pojawia się imię Urszuli Lubienieckiej.

33 Sielankowy obrazek młodego Olbrychta wychowującego się na przedmieściach Rakowa, w dworku Lubienieckiego, zwanym później kościelnym, to fantazja biografów (nie jest nawet pewne, czy dworek ów zwano kościelnym - jak dokładnie - za przekazem S. Malanowicza - powtarza Grześkowiak, czy też przedmieście nazwano później w ten sposób - jak poprawia Gajdka, podejrzewając, zapewne nie bez racji, zepsucie tekstu). Por. K. Gajdka, Ptatnik z pustą skrzynia, s. 171; R. Grześkowiak, Wprowadzenie do lektury, s. 9; S. Malanowicz, Zabudowa miasta Rakowa w XVII i XVIII wieku, w: Raków - ognisko arianizmu, s. 15: „Najdalej wysuniętą w kierunku Dębna posiadłością był dworek na przedmieściu zwany kościelnym przy Rakowie. Należał on do Jakuba Sienieńskiego, a następnie do Stanisława Lubienieckiego”.

34 W Liber amicorum wpisało się kilku innych rokoszan (Joachim Rupniowski, Stanisław Kietliński, Samuel Grądzki, Jan i Stanisław Taszyccy, Marcin Grotkowski, Jan Błędowski, Jan Morsztyn), których nazwiska znajdujemy na akcie z Jeziornej. Por. Liber amicorum (odpowiednio) s. 47, 69, 129, 135, 159, 184, 207; A. Strzelecki, Udziat i rola różnowierstwa w rokoszu Zebrzydowskiego (1606-1607), RwP, 1936, s. 182. 35 W Poloneutychii Andrzej Lubieniecki zdecydowanie potępił rokosz sandomierski, Id., Poloneutychia, op. cit., s. 88; J. Tazbir, Wstęp, w: ibidem, s. X. Regalistyczne nastawienie „odziedziczył” wnuk stryjeczny i także dziejopis polskiej reformacji, J. Tazbir, Stando Lubentius Moriar. Biografia Stanistawa Lubienieckiego, Iskry, Warszawa 2003, s. 193-194. 
wspólnocie piórem i żywym słowem, musiał więc szukać chleba poza „stolicą” braci polskich. Pierwsza i druga dekada XVII stulecia były więc w jego życiu, jak można sądzić, okresem dworskiej i wojskowej służby. Wtedy zapewne zdobył doświadczenie, które stało się podstawą jego zaciągu w poczet „sług dwornych” Krzysztofa Radziwiłła i funkcji, jakie sprawował w „państwie birżańskim”: porucznika lekkiego znaku, wojskowego intendenta, dworskiego ochmistrza i marszałka. Także lustratora dóbr: wolno przypuścić, że posiadał też praktyczne doświadczenie ziemianina, jakiego mógł nabyć w tamtych latach, gospodarując przez jakiś czas w dziedzicznych Karmanowicach ${ }^{36}$.

Sztambuch Andrzeja Lubienieckiego związał z biografią poety postać Stanisława Kurosza. Ten bowiem wpisał się na stronie 58 Liber amicorum $^{37}$, od autografu autora Wesela towarzyskiego oddziela go jedna tylko dedykacja $^{38}$, nie ma więc przesady w określeniu, że wpisali się razem. W środowisku klientów radziwiłłowskich Kurosz był niewątpliwie osobistością bardziej znaczącą, stał się z biegiem lat jednym z najbardziej zaufanych ludzi Krzysztofa Radziwiłła, więcej też materiałów na jego temat przechowały archiwa. To sąsiadowanie na kartach „księgi przyjaciół”, a więc w okresie „przedradziwiłłowskim”, skłaniało biografów do hipotetycznego łączenia tych dwu życiorysów, nie wolno jednak zapominać, że istniejące dokumenty nie pozwalają wyjść poza domniemania. Twierdzenie, że Kurosz już jako starosta w Orli (został nim ok. 1620 r.) był „wprowadzającym”, który „rekomendował” Radziwiłłowi Karmanowskiego, a ten „czekał w Orli na decyzję księcia”, jest biograficzną fantazją ${ }^{39}$. Chrono-

36 Jeszcze w latach czterdziestych XVII w. rejestr poborowy województwa lubelskiego stwierdza dla Karmanowic własność Jana Karmanowskiego. Może tu chodzić o syna poety. Zob. Rejestr poborowy województwa lubelskiego (powiat lubelski i urzędowski z r. 1626, Ziemia tukowska z r. 1620), oprac. J. Kolasa, P. Szuster, red. S. Ingolt, WTN, Wrocław 1957, s. 131: na temat okresu, którego dotyczy zapis, zob. Wstęp, w: ibidem, s. XII.

37 „Qui profitentur se Christi esse, non tantum ex ÿs, quae dicunt sed etiam ex ÿs, quae faciunt cognoscuntur" / Generosissimo D[omi]no Andreae ex Lubieniec Lubieniecio [zapis zamazany] amico tamquam Patri in $\mathrm{Chr}$ [ist]o observantissimo in perpetuum pignus filialis amoris rescribo / Stanislaus Kuroschius m[anu] p[ropria]”.

38 Na s. 57: wpis Mikołaja Rusieckiego (po śmierci wpisującego oznaczony krzyżykiem i uzupełniony polskim wierszem przez Joachima Rupniowskiego, zięcia właściciela sztambucha).

39 Por. K. Gajdka, Ptatnik z pustą skrzynia, s. 173; Id., Literatura, propaganda, stużba, s. 101. Także możliwość osobistej znajomości Kurosza czy tym bardziej Karmanowskiego 
logia, jaką wyczytać można z zachowanych przekazów, wskazuje na co innego. Kurosz był już dobrze znany w środowisku radziwiłłowskim co najmniej w roku $1616^{40}$. Zachowała się też wzmianka o jego wcześniejszej służbie u księcia Gabriela Bethlena ${ }^{41}$. Radziwiłłowskim sługą mógł zostać także na drodze „przejęcia aktywów” po innym magnacie - przejścia całej grupy sług pod opiekę nowego patrona (Krzysztofa Radziwiłła). Bardzo możliwe, że w grupie tej znalazł się również Karmanowski. Nie ma na to żadnych dowodów, nic jednak nie zaprzecza takiej możliwości i nie jest ona mniej prawdopodobna. Do albumu Lubienieckiego obaj wpisaliby się wówczas już jako „ludzie Radziwiłła” ${ }^{42}$. Wcześniejszy okres radziwiłłowskiej służby Karmanowskiego wiązał się prawdopodobnie z rozjazdami i „pilnowaniem” interesów patrona na obszarze, z którym poeta był naturalnie związany - przede wszystkim z ziemią lubelską (sprawy w Trybunale Lubelskim, misje kurierskie). Najwcześniejsze znane nam listy oficjalistów birżańskich dotyczące poety przynoszą taki właśnie obraz jego zatrudnień ${ }^{43}$. Widoczne w zachowanych dokumentach finansowe zabiegi Karmanowskiego z przełomu 1621 i 1622 r. wiążą się już prawdopodobnie z przeniesieniem się w okolice Słucka. Oczywistym skutkiem tego kroku było ściślejsze związanie z patronem i bliskim mu dworsko-urzędniczym kręgiem ${ }^{44}$. Sam udział Kurosza

z Piotrem Kochanowskim (oparta na pokrewieństwie tego pierwszego z Kochanowskimi) jest hipotetyczna (najszerzej o tym: Id., Literatura, propaganda, stużba, s. 143-145). W świetle dzisiejszej wiedzy literacka „współpraca” obu poetów jest zaś całkowita fantazją, J. Ziembiński, Kawalerowie z różnego kruszcu. Olbrychta Karmanowskiego „recenzja” polskiego Gofreda, „Barok” 16, 2, s. 116, 120-121.

40 Por. list M. Berzeńskiego do Krzysztofa Radziwiłła z 5 X 1616, U. Augustyniak, Dwór i klientela, s. 128, przyp. 140.

41 Wzmiankuje o tym Kurosz w liście do K. Radziwiłła z 9 XII 1929, ibidem, s. 83, przyp. 40 .

42 Związanie się Karmanowskiego z Radziwiłłami mogło poprzedzać także jego małżeństwo - znany wiersz Naborowskiego z frazą: „Książę, wiesz co, ożeń go” ( $O$ Karmanowskim do księcia Radziwita, w. 13) może pochodzić z tego okresu (ok. 1615). Wiersz odnosi się do Karmanowskiego-arianina („że dziś w Rakowie miłościwe lato”, w. 10), nie mógł więc powstać w późniejszych latach, gdy poeta był już ewangelikiem. 43 Listy M. Berzeńskiego i P. Buczyńskiego z 27 V 1621 i 8 VII 1622. Por. K. Gajdka, Ptatnik z pustą skrzynią, s. 175-176.

44 Już choćby dlatego nieobecność Karmanowskiego w grupie literatów „zmobilizowanych”, aby uczcić zmarłego kasztelana wileńskiego Janusza Radziwiłła, zob. A. Sajkowski, Od Sierotki do Rybeńki, Wydawnictwo Poznańskie, Poznań 1965, s. 40-41, nie może być dowodem - jak chciałby R. Grześkowiak - że w tym czasie poety nie było jeszcze 
w zaciągu Karmanowskiego, choć możliwy, pozostaje niesprawdzalną hipotezą $-\mathrm{z}$ istniejących danych można ułożyć całkiem inną, równie prawdopodobną opowieść ${ }^{45}$.

Wszystko to trzeba uzupełnić jeszcze jednym zastrzeżeniem: uporczywe nazywanie Kurosza „przyjacielem” (a nawet „serdecznym przyjacielem” $\mathrm{i}$,wiernym druhem” $)^{46}$ to tworzenie biograficznej legendy zamiast skrupulatnego rozważania szczegółów: istniejące dokumenty nie wskazują na jakiekolwiek emocjonalne zabarwienie ich stosunku (nie zachowały się zresztą listy prywatne). Poza wpisem w sztambuchu Lubienieckiego, sugerującym ślad wspólnoty losów w okresie „przedradziwiłłowskim” (o której nie możemy jednak powiedzieć nic pewnego), po przeniesieniu się Karmanowskiego na teren „birżańskiego państwa” niewiele ich łączy: ani charakter i zakres zatrudnień, ani dworskie „znaczenie”, ani, jak można przypuszczać, poziom materialnego dostatku. Nie zbliżyła ich też z pewnością konwersja Karmanowskiego na kalwinizm. Czy utrzymywali bliższy kontakt także poza koniecznością wynikającą z urzędniczych obowiązków - być może, ale tego po prostu nie wiemy ${ }^{47}$.

wśród sług radziwiłłowskich. W tego rodzaju sprawie - gdy liczyły się nie kwalifikacje fachowe, ale „ideowe” - Karmanowski jako arianin (czy nawet były arianin) nie mógł zostać zaliczony do ludzi najbardziej zaufanych. Wszystko, co wiemy o jego twórczości, nawet rozszerzonej o utwory o autorstwie niepotwierdzonym, choć literacko możliwym, skłania też do przypuszczenia, że był zaprzeczeniem typu dyspozycyjnego dworskiego literata: nie ma w jego zachowanym dorobku śladu związków z Radziwiłłami (właśnie takie wiersze miałyby największe szanse przetrwania), brak też dowodów jakichkolwiek kontaktów literackich z innymi, czy choćby znajomości jego wierszy w środowisku birżańskim. Por. R. Grześkowiak, Wprowadzenie do lektury, s. 7-8.

45 Można tu wspomnieć postać Samuela Grądzkiego, który także wpisał się do Liber amicorum (w 1618 r.) i podobnie jak Karmanowski sygnował akt z Jeziornej, a który bardzo wcześnie (w czasie rokoszu?) związał się z Januszem Radziwiłłem, by po jego śmierci zostać „odziedziczony” przez jego przyrodniego brata, Krzysztofa.

46 K. Gajdka, Literatura, propaganda, stużba, s. 97, 144; Id., Ptatnik z pusta skrzynia, s. $173,175$.

47 W zachowanej korespondencji Karmanowskiego z lat 1625-1630 Kurosz pojawia się trzykrotnie. Najciekawsza jest wzmianka w liście z 22 III 1630 r. Poeta prosi Krzysztofa Radziwiłła, aby raczył wypłacić mu „należność”, by mógł terminowo wywiązać się z zobowiązania, „gdyż na tem tegodniu przed święty przychodzi mi jednać adwersarze synów moich. A obligowałem się ich M[ościo]m p[anom] przyjaciołom, iż to, co Ich Mość według wynalazku swego postanowią dać, mam pewnie, sub nullitate tego jednania odesłać z Sielca przed Wielkąnocą. A nie mam na to dziesiąci kop. Wszytka nadzieja po Bogu w miłościwej łasce W[aszej] Ks[iążęcej] M[ości], że mi, 
Kurosz zmarł w 1646 r., prawdopodobnie niedługo po Karmanowskim. Nie znamy dokładnej daty śmierci autora Pieśni pokutnych, może kiedyś ujawni ją wzmianka szczęśliwie odnaleziona np. w liście któregoś z birżańskich oficjalistów. Na razie wystarczyć musi data przybliżona - była ona przedmiotem wielu spekulacji, warto więc podać oparty na aktualnym stanie wiedzy terminus ante quem zgonu poety: napisanie przez Jana Andrzeja Morsztyna Nadgrobka Otwinowskiemu w roku $1645^{48}$.

ubogiemu człowiekowi, w takim razie i dziatkom moim upaść nie będziesz raczył dopuścić, ani dasz słudze swemu uniżonemu szwankować na sławie i honorze, co by nas pewnie nie minęło, gdybym pochybił terminu oddania pieniędzy. O czym do mnie p[an] Kurosz pisze, kładąc tę kondycyją w głowach za najpierwszą do jednania, którego list W[aszej] Ks[iażęcej] M[ości] posyłam”, O. Karmanowski, Wiersze i listy, s. 84-85, s. 190 [Komentarze]. Wydawca listu wyjaśnia, że pieniądze były potrzebne Karmanowskiemu, aby „doprowadzić do zgody z przeciwnikami w sporze” („jednać adwersarze”) jego synów, a zobowiązanie terminowej zapłaty złożył on „pełnomocnikom prawnym” („panom przyjaciołom”). O jaki spór z nieletnimi synami mogło chodzić i jaki w tym udział Kurosza - nie wiadomo. Można jednak pójść śladem odczytania K. Borzęckiego, odkrywcy listów poety w archiwum nieświeskim, który zrozumiał to miejsce inaczej, por. Id., O Olbrychcie Karmanowskim, s. 100-101. Według niego Karmanowski chce zatrudnić („zgodzić”) dla swych synów korepetytorów (nauczycieli domowych). Jeśli (co bardzo prawdopodobne) poeta poślubił Wiktorię Cettisównę ok. 1615 r., to w 1630 r. przynajmniej jeden z nich miałby 14-15 lat, a więc osiągnąłby wiek „gimnazjalny”. Domyślamy się, że Karmanowski - teraz ewangelik, ale niegdyś „chrystianin” i absolwent zborowej szkoły - chciałby, aby byli to nauczyciele podobni tym, którzy kształcili jego, stąd pośrednictwo Kurosza, który od wiary ojców nie odszedł i nie zerwał zborowych kontaktów. Ci, którzy decydują o warunkach kontraktu (zapłata z góry), pozostający w cieniu i nieco eufemistycznie określeni jako „panowie przyjaciele”, to zborowi decydenci: przy zatrudnianiu nauczyciela on sam nie był stroną umowy, o wszystkim decydowali urzędnicy zborowi, zdolniejszych zaś uczniów przeznaczonych na nauczycieli domowych wyznaczał synod, por. S. Szczotka, Synody arian polskich. Od zatożenia Rakowa do wygnania z kraju (1569-1662), RwP, 1935-1936, s. 4. Tak odczytując ów fragment, moglibyśmy domyślać się, dlaczego Jan Karmanowski, syn Olbrychta (i również radziwiłłowski lustrator) był arianinem...

48 Do określenia daty śmierci poety nie można wykorzystać Nadgrobka Otwinowskiemu w sposób zaproponowany przez R. Grześkowiaka: „Karmanowski nie żył już na pewno w 1642 r., skoro jego duch witał w zaświatach Waleriana Otwinowskiego, zmarłego 9 września 1642 r., w wystawionym mu mu przez Jana Andrzeja Morsztyna okazałym literackim Nadgrobku"; R. Grześkowiak, Wprowadzenie do lektury, s. 13. Karmanowski bowiem żył jeszcze wiosną 1643 r. (w roku tym Wielkanoc wypadała 5 IV: jest to najpóźniejsza znana wzmianka o poecie), przeżył więc Waleriana Otwinowskiego. Morsztyn jednak nie napisał swego poematu zaraz po śmierci „drogiego dziada”, upamiętnił go nim dopiero w 1645 r. - wtedy musiał już wiedzieć o śmierci Karmanowskiego; 


\section{Manu propria. Olbrycht Karmanowski's entry to Andrzej Lubeniecki's Liber amicorum}

The article concerns Olbrycht Karmanowski's entry to Andrzej Lubieniecki's album. The book offriends (Liber amicorum, now stored in Czartoryski Library in Cracow) of Andrzej Lubieniecki, who was a respected writer and Antitrinitarian activist, is a unique object. One can find there the entries of almost all intellectual élite of the Congregation - its ordinary members as well as sympathizers who visited the New Jerusalem of the Polish Brethren.

Karmanowski's entry consists of the proper text and his dedication to Lubieniecki. The main part of the entry was probably taken from some compendium of loci communes. It refers to the Platonic topoi of the world as theatre and philosophy as a preparation to death. It is followed by two Latin aphorisms and their Polish translations in verse added by the poet. These poems are the only poetic autograph of Karmanowski which has been preserved.

Karmanowski's entry to Lubieniecki's album became an important fact in the poet's biography reconstructed with difficulty from the few documents preserved. It was also the basis of the introduction of a Socinian thread to it. The article argues with the idea of Karmanowski's too close connection with the milieu of Raków Congregation (e.g. his alleged studies in Raków College and permanent residence in Raków). It also argues with the place of Stanisław Kurosz (a member of the Congregation and one of the most trusted man of Krzysztof Radziwiłł) in Karmanowski’s biography.

\footnotetext{
albo nie znał jej dokładnej daty, albo „kolejność” nie była dlań ważna z perspektywy odejścia obu. Por. J. Ziembiński, „Łódź wiary prawdziwej”. Wyznaniowe oblicze „Pieśni pokutnych" Olbrychta Karmanowskiego, OiRwP, 2012, 56, s. 63, przyp. 7; W. Weintraub, Wstęp, w: J. A. Morsztyn, Wybór poezji, oprac. W. Weintraub, Ossolineum, Wrocław 1988, s. XL. Zawierający wspomnianą wyżej redakcję tzw. rękopis Komierowskiego, znany wcześniejszym wydawcom Morsztyna (L. Kukulski, W. Weintraub) tylko z mało wiarygodnego dziewiętnastowiecznego przedruku, odnalazł się w 1989 r. i znajduje się obecnie w Bibliotece Narodowej (sygn. akc. 13102).
} 